\title{
Steppe Riders in the East Kimberley Contact Zone: Zoroastrianism, Apocalyptic Judeo-Christianity and Evangelical Missionaries in Australia's Colonised Periphery
}

\section{Heather McDonald}

\section{Introduction}

Around 1200 BC on the Eurasian Steppe, nomadic warriors threatened to destroy the social and moral fabric of Iranian agricultural settlements. Conflicts between steppe riders and settled agriculturalists were cosmicised by Zoroastrian traditions. The concept of 'religion' as a bounded sphere of life separate from secular spheres is a Western invention. Extreme ideas develop in times of crisis - particularly, in warring societies, in the ignominy of defeat. Good/evil and heaven/hell dualisms and an apocalyptic eschatology originated in Iran. During Hellenistic and Roman persecutions (332 BC - AD 312), Jewish and Christian writers produced a flood of apocalyptic writings. In times of success and prosperity, people tend to moderate extreme ideas. In this chapter, I examine the development of Zoroastrian cosmological ideas, their adoption by post-exilic Judaisms and early Christianities, their post-Reformation revival, and their entanglements in the East Kimberley contact zone. ${ }^{1}$

1 Colonial contact zones, 'the social spaces where cultures meet ... often in contexts of highly asymmetrical relations of power' (Pratt 1991: 33), have become the intercultural spaces of negotiation, translation and improvisation (Bhabha 1994: 112). 
I am fortunate to have had Dr Ian Keen, an experienced supervisor of theses on Aboriginal Christianity, with a personal interest in religions that is similar to my own, as both an undergraduate lecturer and a postgraduate supervisor. ${ }^{2}$ Aboriginal religion is one of Ian Keen's main research themes, and he writes of Yolngu/Christian syncretism in Arnhem Land. In Yolngu Christianity, God has been given the role of a cosmogonic ancestor (with the title God wangarr father). The ancestral Djang'kawu Sisters are likened to key biblical figures: Adam and Eve, and Moses. Yolngu people have modelled their Christian baptism ceremony on a traditional washing ceremony (Keen 1994: 284). On Arnhem Land missions and post-mission settlements, Yolngu Christian movements sought 'to establish greater unity within Yolngu social relations, to legitimise new forms of community structure and authority, and to extend relationships of amity to whites through shared sacra' (ibid.: 276). Yolngu Christianity was seen to be developing a parallel course to other universalising religious forms such as the Gunapipi ceremony, which emphasise inclusivity (ibid.: 256).

On East Kimberley pastoral stations, Christian missionisation took a different course. Early pastoralists denigrated Aboriginal ways of being as myall (ignorant) and uncivilised, and early Christian missionaries denounced traditional ritual life as Satanic. Although older Aboriginal Christians talk about ngarranggarni (Dreaming, ancestral) people in the Bible, and claim that Jesus Christ was walking in ngarranggarni time, evangelical missiologies have discouraged active syncretism. ${ }^{3}$ Extreme religious ideas propagated by conservative evangelical churches, ideas which have been muted or discarded by liberal churches, have had adverse effects on Gija and Jaru cosmologies. ${ }^{4}$

2 Doctoral theses on Aboriginal Christianity supervised by Ian Keen include Bos (1988), Hume (1989), and Slotte (1997). Both Ian Keen's father and my father were Christian ministers of religion, though at opposite ends of the liberal-fundamentalist spectrum. Our fieldwork experiences of Christian missionisation were also at opposite ends of the liberal-fundamentalist spectrum.

3 The Assemblies of God (AOG) church espouses a missiology of radical discontinuity (i.e. there is no continuity between Aboriginal practices and Christianity and there must be no admixture of them in Aboriginal Christianity). United Aborigines' Mission (UAM) missionaries claim to follow a middle way between the fairly extreme anti-cultural stance of the AOG church and the fulfilment missiologies of Arnhem Land Christianity which claim that other religions have the same status as the Old Testament in relation to Christianity; that is, they are a preparation for the gospel, and should not be abolished but rather fulfilled in Christ (United Church 1974). For UAM missionaries, although other religions can never claim an Old Testament status in relation to Christianity, God (as well as Satan) may have been communicating with Aboriginal people through their traditions before missionaries arrived with the gospel message. For this reason, missionaries look for 'redemptive analogies' in Indigenous beliefs and practices which can be used to point people to Christ (McDonald 2001: 63-8, 186).

4 On returning to East Kimberley in 2014, I was dismayed to find that Christian missionary demonisation of Gija and Jaru spirit worlds is complete. The ancestral spirits of Gija and Jaru people are translated as 'evil spirits' in Aboriginal-English dictionaries and in texts about East Kimberley people (see Richards and Hudson 1990: 94; Hansen 1992: 53; Wrigley 1992: 63; Burke 1998: 35; Kranenbarg 2004: 3; Zucker 2005: 175; McCoy 2008: xii-xiii; McMaster 2008: 204). In 1989-91, there were Aboriginal people who knew differently, but who did not speak openly about this. They were perplexed by the constant demonisation of their practices by church pastors, especially in light of the revitalisation of Aboriginal practices in the south of the state, but they did not have the historical knowledge to confidently discuss these issues with their church pastors. 
To facilitate my understanding of the Christianisation process I have adopted an (anthropologised) history of religions perspective. It makes no sense to anthropologise Aboriginal Christianity and to leave Western Christianity unexamined as an historical or cosmological given.

[We need] to anthropologize the West: show how exotic its constitution of reality has been; emphasize those domains most taken for granted as universal (this includes epistemology and economics); make them seem as historically peculiar as possible; show how their claims to truth are linked to social practices and have hence become effective forces in the social world. (Rabinow 1986: 241)

Foucault, in his archaeological historicising, recommends treating canonical documents as monuments; that is, as unified systems of knowledge which do not reveal their power relations and discourse strategies. They must be made to speak. In applying archaeological techniques, one does not uncover universal truths. What one uncovers are the political struggles of peoples in earlier historical periods (Dean 1994: 215; Berkhofer 1995: 4-11; in McDonald 2001: 4).

Cultural amnesia renders opaque to religious believers the socially constructed nature of their concepts, texts and orders of truth. Extreme religious views take on the status of universal truths. But a careful archaeological analysis of ancient Central and Western Asian traditions can help to uncover the peculiar and particularistic antecedents of Western Christianity. In the East Kimberley contact zone, Eurasian Steppe riders (in evangelical Christian guise) have become entangled with Indigenous spirit worlds. But the first three generations of proselytised East Kimberley people interpreted evangelical Christianity according to an older, more humane (kin-based) tradition. Their land-based cosmologies and kin-based moralities blurred, and even subverted, ZoroastrianChristian dualisms.

\section{Zoroastrian Literature}

In the third millennium $\mathrm{BC}$ waves of proto-Indo-European peoples migrated east from the Black Sea. Some (later called Indo-Aryans) settled in northern India and others (later known as Iranians) moved onto the Iranian plateau. Zarathustra (the purported founder of Zoroastrianism) is said to have lived in northeast Iran around 1200 BC (Clark 1998: 18-9). Avestan Gathic hymns, the earliest layer of Zoroastrian literature, were composed in a very old Iranian dialect, close to Vedic Sanskrit (Foltz 1999: 27; Shaked 1984: 311). The Old Avesta (including the Gathas) reached its final form about $1000 \mathrm{BC}$, and the Young Avesta about 700-550 BC (Skjaervo 2011: 2). Although the Vendidad contains recent sections, it began to be written before the eighth century BC, and most of its subject matter is very old (Kellens 1989: 35). 
Early Zoroastrian literature depicts an agricultural society devoted to cultivation of the land and cattle husbandry (Clark 1998: 13, 23). According to the Old Avesta, the gods brought irrigation and cultivation to Iran (Skjaervo 2011: 42). 'He who cultivates grain, cultivates righteousness' (Vendidad III.3.31, in Settegast 2005: 10). Zarathustra's world was also a world of hierarchising city-states. In the Avesta, the world of the gods (the 'world of thought') had already separated from the world of living beings (the 'world with bones') (Skjaervo 2011: 8). Zarathustra transformed the Iranian pantheon, elevating Ahura Mazda, the Herd-giver, to the position of Supreme Being. Iran's lesser gods were organised into Ahura Mazda's heavenly court (Clark 1998: 44-9).

\section{The Eurasian Steppe}

Central Asian history is defined largely by the dynamics of nomadic-sedentary relations, often hostile, even violent, but always mutually interdependent. (Foltz 1999: 23)

The Eurasian Steppe stretched 4,000 kilometres from the Black Sea to the frontiers of China. It supported nomadic herders driving oxen, sheep and goats in search of pasture. Herders traded with, and raided, settled agriculturalists for what they could not produce. In response, agriculturalists built defensive walls around their settlements. Nomadic pastoralists and settled agriculturalists entered into a long and difficult relationship which lasted for well over 2,500 years (Foltz 1999: 23).

Horse-mounted herding developed early in the first millennium BC (Beckwith 2009: 60). Nomadic herders developed a warrior culture, revering warriorancestors, and sacrificing to sky-war gods. Warrior bands made forays into agricultural settlements, seizing herds and driving them to mountain strongholds (Cohn 2001: 90; Settegast 2005: 87). Over time, nomadic warrior bands came to exercise a kind of suzerainty over the lowland cities (Beckwith 2009: 343-6; Skjaervo 2011: 16, 51-3).

\section{Zoroastrian World View}

Extreme ideas develop in times of crisis - particularly, in warring societies, in the ignominy of defeat. Zarathustra welded nomadic-sedentary struggles into a cosmic conflict between good and evil (Nigosian 1993: 24). Creation stories involving a primal struggle between chaos and order were widespread in the ancient world. Zarathustra transformed the ancient combat myth into an absolute moral principle. The cosmos was permeated by a fundamental tension between 
light and darkness, good and evil (Nigosian 1993: 88). Ahura Mazda became the origin of good and Angra Mainyu the origin of evil. Angra Mainyu attacked Ahura Mazda's ordered cosmos, bringing chaos and death (Skjaervo 2011: 8, 65).

In early Iranian traditions, all the dead went to a shadowy netherworld. Later, as politico-cosmic structures hierarchised, the elite were directed to a paradise in the sky, and the rest to the netherworld (Cohn 2001: 96). The concept of a heavenly paradise derives from Old Persian pairidaeza, the enclosed garden of the Persian king (Russell 1997: 31). In early city-state societies, this world was a world of moral order. Moral imbalances needed to be redressed at the time they occurred for life to proceed with equanimity. But in Zarathustra's time, nomad warriors transgressed against agriculturalists and avoided punishment. In the Gathas, the netherworld was transformed into hell, a place of afterlife punishment and torment (Cohn 2001: 96-102). ${ }^{5}$

Zoroastrian apocalypticism is a very old tradition (Boyce 1984b). Thoughts of evil people suffering in an afterlife no longer satisfied the righteous. The forces of evil needed to be eliminated from this world. The Gathas introduced the Saoshyant, a world saviour, who will end the present era and usher in an era of righteousness (Skjaervo 2011: 29). The Saoshyant will lead the righteous against Angra Mainyu's hordes and the dead will be resurrected to face the Last Judgement. Good and evil people will be separated. In a worldwide conflagration, Angra Mainyu will be annihilated and the righteous purified to share the Kingdom of Ahuramazda. There will be no sickness, suffering or death (Boyce 1984a: 300-1; Nigosian 1993: 94-5). The Gathas convey a sense of great urgency about the coming apocalypse (Clark 1998: 15, 64; Cohn 2001: 98-101).

\section{Persian Empires (559 BC - AD 650)}

Jews, Christians and Moslems you are, in your system of spiritual beings, nothing but straying children of Zoroaster. (Volney 1791: 146, in Cohn 2001: 239)

In 546 BC, Cyrus II, King of Persia, invaded Asia Minor, and developed an empire which stretched from India through Mesopotamia to Syria. Zoroastrianism became the official religion of three Persian empires: Achaemenid (559-331 BC), Parthian (247 BC - AD 224), and Sasanian (AD 224-650) (Skjaervo 2011: 1).

5 The modern English word 'hell' derives from Old English hel, helle (c. AD 725) referring to a netherworld of the dead, reaching back to the Anglo-Saxon period, from Proto-Germanic halja, meaning 'one who covers up or hides something' (Barnhart 1995: 348). After Christianisation, Old English hel followed the same trajectory as Greek Hades and Hebrew Sheol, becoming a place of afterlife punishment and torment. 
Monotheism is a product of empire. ${ }^{6}$ During the Achaemenid empire, Ahura Mazda was transformed from Supreme Being to Universal God (Nigosian 1993: 71-2). If extreme ideas develop in times of crisis, we can also see that in times of success people are able to moderate extreme ideas. During the Persian empires, apocalyptic eschatology was de-emphasised (Cohn 2001: 102). ${ }^{7}$

After their release from Babylonian captivity, many Jews remained in the region, contributing to the Persian/Babylonian economy and east-west trade (Clark 1998: 152). The books of Daniel and Esther are set in the Persian court. ${ }^{8}$ Persian court administration is also evident in Ezra and Nehemiah (Shaked 1984: 308-14). At the Persian court, Ezra and his scribes reworked ancient Hebrew texts and developed the 'Law of Moses' (Lee 2011). The Jews in Persia were well on the way to becoming monotheists (Clark 1998: 153). ${ }^{9}$ Among the returnees to Judea, Persian ideas contributed to new forms of piety. The Hasidim, an exclusivist sect, developed a scrupulous observance of Zoroastrian-Jewish purity laws (White 2004: 20).

\section{Hellenism (c. 332 BC - AD 100)}

In 332 BC, Alexander the Great defeated Persia and developed the Macedonian empire. Greek cities and temples were established in Palestine. Jewish elites benefited from Hellenisation but the Hasidim opposed it (Cohn 2001: 174). On Alexander's death (323 BC), the empire split into two, the Seleucids and Ptolemies, who fought five major wars in the third century BC with Judea as battleground and prize (Shanks 1998: xviii). In 167 BC, the Seleucid monarch, Antiochus IV, rededicated the Jerusalem Temple to Zeus, and banned study of Torah, Sabbath observance and circumcision on pain of death (Vermes 2004: 51). When resisted by the Jewish faithful, Antiochus IV destroyed Jerusalem and the temple. The Jewish Hasmonean family which drove Antiochus IV out of Jerusalem, later assumed the Judean monarchy and high priesthood (Shanks 1998: 95; Cohn 2001: 167).

\footnotetext{
6 Zoroastrian monotheism was not the first monotheism to be introduced in Central or Western Asia. Akhenaten (1353-1335 BC) imposed a monotheistic regime on the Egyptian empire by promoting the sun disc, Aten, to Universal God, naming himself as Aten's son, and suppressing all other deities (Silverman 1991: 81). 7 Apocalyptic ideas were reignited by Alexander the Great's conquest of Persia (332 BC) and by the later Muslim conquest (AD 633) (Cohn 2001: 102).

8 The Book of Daniel contains many Zoroastrian ideas. Nebuchadnezzar's prophetic dream mirrors a much older Zoroastrian work, the Zand-i Vohuman Yasht (Cohn 2001: 222-30).

9 Universal gods may outlive the empires that produced them. The hybrid (Zoroastrian-Jewish-Platonic) God of the Roman Empire became the Universal God of the Western European powers. Monotheistic regimes attempt to suppress religious pluralism in their territories. In Australia, evangelical monotheists continue to demonise and suppress Indigenous spirit worlds.
} 


\section{A Changing Jewish World View}

For peoples of the ancient world, this world was a world of moral order. The early Israelites had no concept of hell (Foltz 1999: 32). But Antiochus IV's persecution fell on the righteous. The Persian word for heaven-pairidaeza (pardes in Hebrew translation) - appeared in Jewish literature at this time (Clark 1998: 154). In Greek Orphic traditions (which had absorbed Zoroastrian ideas), moral imbalances in this world were resolved by afterlife retribution (Herrero de Jáuregui 2007: 306). ${ }^{10}$ Some Jewish groups transferred retribution to the afterlife. Sheol (Hades in Greek translation) became a place of temporary punishment (Rudman 2001: 241). At some point, Gehinnom, a valley of human bones outside Jerusalem, became linked with Sheol/Hades (Papaioannou 2004). ${ }^{11}$ Ideas about afterlife retribution were in flux in Jesus' time, and were rejected by some Jewish groups including the priestly Sadducees (Cohen 2006).

Before contact with the Persians, the Israelites did not harbour apocalyptic ideas. Temple cults functioned to maintain an ordered universe rather than eliminate disorder from the world (Cohn 2001: 114). Zoroastrian ideas were fixed in chants and temple recitations. They travelled along trade routes and were discussed in the market place (Foltz 1999). Apocalyptic ideas resonated with Jews who experienced Antiochus IV's persecution (Russell 1994: 107-9). Jewish writers developed a belief in an earthly messiah who would restore the Kingdom of David (Clark 1998: 154). By around 150 BC, the messiah had come to be seen as a heavenly figure who would usher in the Kingdom of God. This understanding is expressed in Second Temple period apocryphal literature including the Dead Sea Scrolls (Shanks 1998: 68-9, 167).

During the Hellenistic period, Jewish (and later Christian) writers produced a flood of apocalyptic writings (Russell 1994: 2). Moses, Solomon and Enoch were appropriated as intermediaries who provided safe passage to celestial realms. Satan, a bene ha-elohim (son of the gods) was transformed into an opponent of God and cast out of heaven (Cohn 2001: 179-85; Russell 1977: 190-204). ${ }^{12}$ The notion of fallen angels can be traced to Orphic (and Zoroastrian) ideas

\footnotetext{
10 Macedonian imperial expansion (333-30 BC) destroyed the Greek city-states. The displaced Greek aristocracy sought salvation from earthly existence by initiation into mystery cults. Plato brought Orphic traditions (which had absorbed Zoroastrian ideas) into mainstream Greek thought (Collins 1998: 35; Herrero de Jáuregui 2007).

11 Gehinnom was the place where the Israelites, during the reigns of Ahaz and Manasseh, sacrificed their children to the god Moloch (Joshua 15:8; II Kings 23:10) (Kohler and Blau n.d.).

12 The term elohim made many shifts in meaning from 'the dead' to 'the gods' to 'God' in line with changing politico-cosmic structures. During the Babylonian exile, the Hebrew bene ha-elohim were transformed from sons of God to angels. Satan became a prosecutor in the heavenly court of Yahwel-El. In later apocryphal texts, he was transformed into an opponent and accuser of God, lying in court and obstructing the path of truth. He tempted humanity to sin and was cast out of heaven and bound in a pit (Russell 1977: 109-204).
} 
(Shaked 1984: 324; Collins 1998: 35). The Qumran community, an offshoot of the Hasidim who fled to the Judean desert during Antiochus IV's reign, saw themselves as the True Israel (Vermes 2004: 46, 200-10). But Persian dualism is evident in the Tractate of the Two Spirits and The Scroll of the War of the Sons of Light Against the Sons of Darkness (Shanks 1998: 166-9).

\section{Zoroastrian-Christian World View}

In $63 \mathrm{BC}$, Mesopotamia became a battleground between the Roman and Parthian (Persian) empires. Apocalyptic eschatology, now part of mainstream Jewish thinking, became available to early Christianities (Shanks 1998: 170). Christian groups in Syria, Asia Minor and Greece had come to see Jesus as divine. In the first three centuries of Christianity, particularly during Roman persecution, extreme religious ideas flourished, including expectations of an imminent apocalypse (Chidester 2000: 29-31). The Gospel of Matthew, most likely produced by a Syrian Jewish-Christian community around AD 80-90, contains many Zoroastrian ideas (Duling 2010: 298-302). Jesus will return as the Son of Man (a Zoroastrian term) to resurrect the dead to face the Last Judgement (King 2003: 72). In a worldwide conflagration, the wicked will be annihilated and the righteous purified to share the Kingdom of God (Cohn 2001: 228-9).

In Jesus' time, many Jewish groups believed in Sheol/Gehinnom (Hades/ Gehenna in Greek translation) as a place of afterlife retribution. In the gospels, Jesus' sayings reflect these views. The early theological schools at Alexandria, Antioch, Caesarea and Edessa, established around AD 100, combined Jewish understandings of afterlife retribution with Greek metaphysics. Hades/Gehenna became a place of remedial punishment. The theology of universal restoration (the view that God will redeem all humans), was influential in the Eastern Church (Repas 2009: 16-7).

However, the bishopric see of Rome developed a different interpretation. The Roman school, influenced by Roman law, introduced the concepts of original sin, human depravity, vicarious atonement, and eternal punishment. Irenaeus, Ignatius, Justin Martyr, Athengorus and Tertullian wrote tracts on eternal punishment in hell (Repas 2009: 17). Political manoeuvring (including the claim to be in apostolic succession from the apostle Peter) allowed the Roman school to become pre-eminent (Chadwick 1990: 237-46; Repas 2009: 20). ${ }^{13}$

13 The Zoroastrian notion of purification by fire, and the Jewish (and Eastern Christian) view of Sheol/ Gehinnom as a place of remedial punishment, found a place in the Roman Catholic doctrine of purgatory (Zaleski 2012). 


\section{Allegorical versus Literalist Exegetical Traditions}

The early Eastern and Western Church fathers promoted allegorical interpretations of the Hebrew scriptures. They used Middle Platonic speculation about the realm of Being, the realm of becoming and the mediating logos, to develop a Christian logos theology which subordinated Hebrew texts to the Platonic voice (Dawson 1992: 187-9, 239). ${ }^{14}$ This allegorising tradition continued throughout the European Middle Ages. But the Protestant Reformation created a literalist turn. Lutheran emphasis on sola scriptura (scripture alone) and Protestant emphasis on a plain-sense reading of the Bible led to literal interpretations of biblical texts (Hannam 2009: 226). Although the European upper classes were intent on keeping the lower classes illiterate, Puritans and evangelicals encouraged literacy so that everyone could read the Bible (Graff 1991). ${ }^{15}$

In seventeenth- and eighteenth-century Europe, extreme religious ideas were revived in response to a new crisis. The rationalising discourses of the scientific revolution and the Enlightenment, particularly the new geological and biological sciences which contradicted biblical 'history', led to the development of pietistic religious societies in High Anglican and Calvinist circles. English Puritanism and German mystical pietism ignited in the person of John Wesley to produce the eighteenth-century evangelical revival which swept through European Christendom spawning Pentecostal experiences, millennial expectations, and missionary fervour (Turner 2002). This evangelical revival, and the American revivals which followed, paved the way for missionary enterprises in East Kimberley.

\section{The Concept of Religion}

In the ancient world, gods, spirits and the afterlife were not features of a sphere of life called 'religion'. Religio in Roman culture related to a person's civic responsibilities. The term came to be synonymous with cultus, the proper observance of rituals, including sacrifices to city founders and military heroes,

\footnotetext{
14 Middle Platonism embraced features of Aristotelian physics, Pythagorean metaphysics and Stoic ethics (Dawson 1992: 189).

15 In Australia, the evangelical missionary focus on Bible translation and linguistic research can be seen as an extension of post-Reformation literacy for converts. Aboriginal-English dictionaries published by the Summer Institute of Linguistics in Darwin and the Institute for Aboriginal Development in Alice Springs reveal traces of evangelical Christian doctrine. In contrast, Catholic missionisation relied on performance rather than intellection. Liturgy, sacraments and oral traditions were given greater prominence than the (written) Word (McDonald 2001: 167).
} 
which maintained the politico-cosmic order (White 2004: 129). After Christianity became the official cultus of the emperor Constantine, the concept of 'religion' developed and changed within a Christian context.

In the first three centuries $\mathrm{AD}$, there were many Christianities. Rival Christian groups produced their own gospels but the questions that primarily concerned them were ones of practice, not theology (Pagels 2003: 15, 179). In AD 312, Constantine recognised only the best organised and largest group as the lawful and most holy catholic church' (Eusebius, Historia Ecclesiae 10.6, in Pagels 2003: 168). In order to create a unified Christendom, Constantine ordered Christian bishops to develop the Nicene Creed. Christianity, always a syncretism, invented itself as a 'pure form' by excluding competing groups, including Jewish Christians and Gnostic Christians as hybrids/heresies (Boyarin 2004: 28-9). Doctrine rather than practice defined true religion. However, the boundaries around Jews, Christians and pagans were not firmly established until the fifth century AD (White 2004: 297, 437). ${ }^{16}$

In thirteenth-century Europe, theology was the most important branch of knowledge. The Church saw moral and natural philosophy as aspects of the same unified discipline but deemed natural philosophy the servant of theology. Conflicts between science and scripture were accommodated by fitting new knowledge into the Church's interpretive framework. But in the seventeenth century, Francis Bacon, Galileo and Descartes removed science from the Church's reign over the nature of truth (Rowland 2001: 57-72, 145-9). In Western societies, religion was reinvented as a distinctive, even sui generis, phenomenon, separate from the secular spheres of politics, economics and science. It is conceived as a transhistorical and transcultural order of reality which (strangely) assumes a Christian soteriological guise (Asad 1993: 27-9; Fitzgerald 2000: 14, 55-6, 71).

\section{Hunter-Gatherer Cosmologies and Evangelical Missionaries in East Kimberley}

Hunter-gatherer societies which practiced 'aggressive egalitarianism' (Woodburn 1982) did not develop a hierarchical political order or a cosmic world above/ world below dualism onto which other dualisms (spirit/matter, good/evil, God/ Satan) could be grafted. Cosmologies follow polities.

16 In the third century AD, Origin of Alexandria wrote of Jewish Christians who attended synagogue on Saturday and church on Sunday. Some Jewish Christians attended synagogue and observed Jewish laws well into the fourth century AD (King 2003: 41). And there are people who identify as Jewish Christians to this day (Boyarin 2004: 48) 
The Australian pattern is not one of celestial withdrawal, but of terrestrial transformation and continued presence ... Connection with the ancestors is on the terrestrial plane, and it is forever available ... There is no 'celestial rupture' that needs to be overcome. (Smith 1987: 5)

Reincarnation cosmologies also follow the cyclical imperatives of the living world. In East Kimberley, all the dead went to the ancestral spirit place, a place in the country invisible to ordinary people except in dreams. Mabarn (clever men/healers) could 'see' and visit the spirit place. Jurnbabarlibarli (song finders) would sleep at the spirit place in order to receive song ceremonies from their ancestors. When mamu and juwarri (spirits of the dead) became tired of living as disembodied spirits and decided that their families could manage without them, they returned to the outside world via the body of a living woman. ${ }^{17}$ They transformed themselves into their 'totem' animal (their true Dreaming shape), entered the mother's womb, and garaj wajarn (became a body), that is, became a new human being. Aboriginal spirit beings are much more complex than simple dualisms allow for. In East Kimberley, humans and spirits do not subscribe to absolute moral values. Gija and Jaru people, who are able to tolerate contradictions in people and in the world, do not feel the need to totally isolate and displace bad events and people (via a good/evil dualism).

Evangelical Christian missionaries arrived in Australia's colonised periphery with concepts developed over 3,000 years of city-state development, wars and empirebuilding in Central and Western Asia. These concepts were refined within the Persian and Macedonian empires, and found their way into diverse scriptures. When Christianity became the official cultus of the Roman Empire, apocalyptic eschatology was de-emphasised. In The City of God, Augustine of Hippo (AD 354-430) equated the millennium with the present spiritual reign of the Church (Allis 2001: 3). ${ }^{18}$ But after the Protestant Reformation, particularly during the seventeenth and eighteenth centuries, apocalyptic ideas were re-awakened by newly literate European and American populations (Balmer n.d.).

17 Mamu (Jaru) and juwarri (Gija) are ancestral life-forces which cycle between the spirit world and the outside world (the world of humans and animals) via reincarnation. As independent spirits they are most powerful because they can see, hear and travel vast distances to access knowledge-power. They can act as invisible forces in the outside world or they can make themselves visible by taking on the form of an animal or other life form.

18 In the late second and early third centuries $\mathrm{AD}$, literal and allegorical interpretations of the apocalypse vied for supremacy. By the mid-fourth century, allegorical interpretations had become dominant. The apocalypse as an allegorical story dominated Eastern Orthodox and Roman Catholic churches throughout the Middle Ages (Alexander 1985). 
During my initial fieldwork in Halls Creek, Assemblies of God (AOG) and United Aborigines Mission (UAM) pastors were preoccupied with apocalyptic eschatology. ${ }^{19}$ 'When [an AOG pastor] first came to Halls Creek [in 1982], he said Jesus is coming very soon. We haven't got time for language translation work' (Jenny Summers, UAM). ${ }^{20}$ AOG sermons frequently focused on the torments awaiting unbelievers. 'The whole earth will burn. When you've been in hell for thirty seconds you'll believe' (Pastor Phillip, AOG). The UAM pastor, presenting a series of sermons on the Book of Revelation, took a softer approach: 'During the Great Tribulation non-Christians will be given a second chance to receive Christ' (Pastor John, UAM).

In Halls Creek, Aboriginal Christians in the evangelical churches propound an eschatology which bears traces of Zoroastrianism:

The pastors are preaching in the desert. There are seven more places in Australia to hear the word [of God]. When the word has gone right through, Jesus will come back. He's having a spell first. As soon as all the Aborigines have heard the gospel, Jesus will come back. (Laurie Jacobs, AOG)

When Judgement Day come, everybody will wake up, even mamu [spirits of the dead] what got drowned in the sea or burned. They still come out. God gotta judge us now. Good person, he tell to go to his side. Satan other side with his mob. If your name not in the Book, he say, 'I don't know you. Cast into hell'. (Lizzie Tracker, AOG)

In East Kimberley, the ghost of Zoroastrianism also looms over evangelical missionaries' attempts to interpret Aboriginal cosmologies. The missionaries' favoured dualisms (God/Satan, good/evil, and heaven/hell) are unmediated by Clement's logos theology or by any other humane tradition:

There are only two powers in this world, that of darkness and that of light, that of Satan and that of God. On Judgement Day, humanity will be separated into two groups: one will spend eternity with God. The other will spend eternity in hell. (Pastor John, UAM)

19 In 1989-91, I conducted research in East Kimberley for my doctoral thesis at The Australian National University. During 2002-05, I conducted research in the same region while a research fellow at the Australian Institute for Aboriginal and Torres Strait Islander Studies. I returned to East Kimberley in 2014 to assist with the recording of family histories. The preoccupation of UAM and AOG pastors with apocalyptic eschatology continues to this day.

20 The names of Kimberley people have been changed to protect their privacy. 


\section{Good/Evil Dualism}

Early missionaries to the Kimberley aligned Aboriginal spirit beings, ancestral snakes and traditional healers with Satan's realm. They recategorised mamu and juwarri (spirits of the dead) as the evil spirits or demons of Christianity. However, for Gija and Jaru people, the Devil who comes from hellfire is evil, but other devils (mamu and juwarri) are not so evil. Some are not evil at all. In East Kimberley, goodness and badness intermingle. Rather than a good/evil dichotomy, there appears to be a continuum of moral attribution which reflects a kin-based ethos. One's family spirits are good devils. Other people's spirits can be half-good devils. The spirits of traditional enemies are commonly referred to as 'half mamu and half cannibal' (Laurie Jacobs) or as 'the biggest Satan' (Alice Sim). In East Kimberley, family spirits assert their 'traditional' attributes of caring for country and people, and in doing so, blur cosmic dualisms.

What person die, he come back spirit mamu and look after his own family. You can sleep anywhere la flat [country]. Anyone sneak up la you, he wake you up. 'Shift your blanket that way. Watch that road'. He guide you back to your camp. (Gabriel Jordon, UAM)

Mamu heal people too. If I sick, I got my mamu. Just like Jesus Christ. My mother [deceased] hang on to me. I ask him, 'I feel headache, Mum. Just feel my head'. I go to sleep. In the morning I feel better. That's mother mine, that mamu. (Tracker Dinggul, AOG)

Family spirits have well-developed nurturing qualities, and according to some Christians, even take on Logos-Jesus roles of identifying with and sharing the human condition. But they do not follow God's way. They follow the traditional way. They are bound by kin-based loyalties, prejudices and emotions. Sometimes they want everyone to be friends; at other times they incite hatred and division. This is a problem for middle-aged Aboriginal Christians who, as children, received a mission education at Moola Bulla government settlement or Fitzroy Crossing UAM mission, and have assimilated Christian moral values:

Juwarri haven't got Christian love. They jealous. They tempt people to fight and swear. God don't like juwarri because they doing the wrong things. I wouldn't say that juwarri hate God. (Alice Sim, UAM)

My granny tell us, 'We'll be juwarri for you mob kid [when we're dead]. We'll be here, all the spirit'. They look after their own family. Nother way round, juwarri can make people wangala [mad, witless]. You'll climb up the hill. You'll walk bush and die. (Sarah Peters, AOG)

For AOG pastors in Halls Creek, all representations of serpents in all cultures symbolise Satan. In East Kimberley, Garluruny (ancestral snakes) are powerful generative forces which are locally exclusive to the point of extreme jealousy. 
When confronted by strange presences or behaviours, they may become violent, generating storms and floods to sweep the intruders away. However, East Kimberley people emphasise the importance of ancestral snakes to the health of country and people. 'Every place gotta living water. Garluruny hold that water. If Garluruny leave that place, water will dry up' (Laurie Jacobs, AOG). Middle-aged and older Christians exempt their ancestral snakes from connection with Satan, and claim their connection with God. 'God made Garluruny. Garluruny belongs to God. When Christians swim in the waterhole, he can't hurt them. When we swim in the healing waterhole, Garluruny heal us' (Alice Sim, UAM). ${ }^{21}$

Although evangelical pastors categorise mabarn healing as witchcraft, many Aboriginal people take a more considered view. Some Aboriginal Christians say God endowed Aboriginal healers with mabarn power at a time when there were no gardiya (whitefella) doctors or hospitals in Australia. Others claim that 'mabarn [healers] are the same as Jesus and God'. Their role is one of reconciliation and restoration of social order. When people have been 'jealousing and fighting', mabarn tell them, 'You fella gotta friend up now' (Alice Sim, UAM). For older Aboriginal people, 'God can't say nothing [about mabarn healing]. White doctor is mabarn too' (Saddleman, UAM).

\section{Christian/Sinner Dualism}

AOG pastors in Halls Creek make an absolute moral distinction between Christians and non-Christians:

The Bible says there are two kinds of people in the world: the children of God and the children of the Devil. The children of God do righteousness and love the Christians. The children of the Devil do unrighteousness and hate the Christians. (Pastor Daniel, AOG)

AOG pastors counsel their adherents not to associate with people (including relatives) who are not AOG members. A pastor told Sally Wilmirr not to 'have that sinful woman [a close relative] in your house'. He advised Paddy Ejay not to talk to his brother who was applying for land by pastoral excision. AOG adherents are instructed to avoid Aboriginal community-controlled organisations and government departments involved in Aboriginal affairs. Vinni Manday, an East Jaru speaker, was counselled not to 'get mixed up with that language mob [Kimberley Language Centre] or any kind of business

21 Caroline Pool, the baptising water for the UAM mob, is also the home of a well-known Garluruny. According to UAM adherents, he was initially frightened by Christian baptisms and swallowed a horse in retaliation. Today he favours the Christian mob and tends mainly to swallow sinners (McDonald 2001: 167). 
[Aboriginal cultural activity]. Those places are full of devils' (Pastor Phillip). Kelly Jangala was told to stop making boomerangs for the Yarliyil Art Centre. 'It will drag you down' (Pastor Daniel).

Aboriginal people in Halls Creek also make a clear divide between Christians and sinners. Sinners 'drink, swear and fight, play cards, chew tobacco, dance corroboree' (Gabi Cousins, AOG). Christians 'go to church, pray for people, heal people, love everybody' (Hilda Saddleman, UAM). 'Card places' (places where card games are held) and 'grog places' (places where drinkers congregate) are sinner places, as are the race course and the circus which comes to Halls Creek at race time. The licensed store on the corner of the main street where drinkers congregate is referred to by AOG adherents as 'that Devil corner'. When Christians drive past the Devil corner at night they are vulnerable to having a tyre puncture.

However, in Halls Creek the Christian/sinner divide is blurred by a kin-based morality. There is a constant flow of people and resources between Christian and sinner domains. Aboriginal Christians ask sinner relatives for their winnings from card games to fund church travel. Christians join card games when they are away from Halls Creek or when the pastor is away. When Christians experience 'too much trouble' in their daily lives, particularly constant demands or failure of obligation from relatives, government, or church pastors, they frequently 'fall back' to card playing, drinking and fighting.

Some Aboriginal members of the evangelical churches pressure family members to give up drinking and come to church. At church, they cajole their kin to go forward to the altar to 'give their heart to the Lord'. If they do not do this, the churchgoers will no longer look after them. They may throw close family members out of the house when they revert to a drinking lifestyle. 'Bessie threw [her drunk sister] out like rubbish' (Gabriel Jordan, UAM). Other church members are tolerant of sinners and backsliders and do not follow their pastors' directives. Families with large numbers of adult children are unable to achieve the ideal state of all family members being sober and churchgoing at the same time. These church members find that their pastors frequently fail to demonstrate Christian love. On one occasion, a young woman opened her well-underlined Bible and read, "If anyone says, "I love God", yet hates his brother, he is a liar, for he who does not love his brother whom he has seen cannot love God whom he has not seen' (1 John 4:20). On other occasions, church members threaten to, and do, take their families out of the churches.

In Halls Creek, half-Christians straddle the divide between Christians and sinners. They enjoy the benefits of churchgoing, particularly the perceived benefits of prayer and healing, but insist that they 'can't be perfect all the time' (Sarah Fielder, AOG). Half-Christians practice 'sin sneaking', that is, they engage 
in sinful activities behind the pastor's back. They tap into different kin networks according to whether they are in churchgoing or backsliding mode. Like sinners, half-Christians frequently become sick as a result of their sinful activities and lack of concern for their physical welfare. When they need respite from the treadmill of drinking, lock-up and injury, they utilise their churchgoing kin and return to church for healing. When their health is sufficiently restored, and they become bored with church activities, they utilise their sinner kin networks to return to a drinking lifestyle. At death, the destination of half-Christians is neither heaven nor hell, but reincarnation:

Spirit for Jimilu [deceased] always hang around our camp. Two-ways bloke, playing card, swearing and fight, he don't go up [to heaven]. He hang around here. Then he come back to mother and father [as a human being]. (Laurie Jacobs, AOG)

\section{Heaven/Hell Dualism}

In Halls Creek, all but the oldest Aboriginal people accept the ZoroastrianChristian heaven/hell divide. This dualism is clearly a very old feature of missionary evangelism in East Kimberley. Gehenna's flames feature in Aboriginal people's descriptions of hell: 'Hell is hot and burning and smell. The rivers and waterholes are boiling. Devil standing up gotta biggest fork' (Gabi Cousins, AOG). Young people's reasons for joining the evangelical churches frequently include the fear of hell: 'I became a Christian because [an AOG pastor] preached about hell and fire. I was frightened. I went to the front [at the altar call] and gave my heart to the Lord' (Danny Hawk, AOG).

But the heaven/hell distinction is blurred by a number of factors. Gija and Jaru spirits are not individualised immortal souls. Spirit is a stream of life which manifests itself in different forms. When a life form dies, the spirit is reincarnated in a new form. According to some Aboriginal people, even Christian spirits are reincarnated. When Christian spirits go to heaven, God sends them back to be reincarnated. Some Aboriginal Christians are not prepared to consign their living or dead relatives to hell. Spirits of the dead in caves and graveyards are waiting for the Second Coming of Jesus. On Judgement Day, Jesus will take everyone to heaven because he loves all sinners (Sadie James, AOG). Hell, the abode of Satan and his demons, is uninhabited (and will always be uninhabited) by Aboriginal spirits (McDonald 2010: 62). Sadie James, who has access to an older, more humane (kin-based) tradition, has modified AOG doctrines about heaven and hell. In her theologising, she has unwittingly stumbled upon the Alexandrian school's theology of universal restoration. Clement of Alexandria 
would not tolerate the thought that any soul would forever resist the force of redeeming love. Sadie's views are closer to Greek metaphysics than to the punitive Roman concepts that inform AOG doctrines.

\section{Younger Aboriginal Christians}

Younger Aboriginal Christians in Halls Creek, many of whom have been recipients of missionary teaching since childhood, appear to have adopted extreme evangelical views which denigrate Gija and Jaru cosmologies.

Dad reckon little rayi was good, but I don't. ${ }^{22}$ Little rayi and little demon, I reckon it's all evil. (Liby Sheeran, UAM)

Mamu and juwarri (spirits of the dead) are the Devil disguising himself as a person who died.

Mabarn [healing] power comes from Satan. Satan can form any miracle because he's the Prince of Darkness. (Louis Jabul, UAM)

Snake represents Satan. I used to believe in Garluruny Snake. Now I believe in one Creator. (Jimmy Esau, UAM)

Some corroborees get tangled up with evil spirits. They singing songs like spirits. You gotta be careful because Satan can use these things. (Louis Jabul)

When we die, our spirit can't come back again, walking around. Christian spirit goes to heaven. Lost people that don't know the Lord, their spirit just floating around. They don't come back and walk around like a dog or cat. They gotta wait for Judgement Day. If they die with sin in their heart, they'll be heading for hell. (Liby Sheeran)

However, rejection of local cosmologies does not translate into freedom from land and kin-based protocols. In East Kimberley, countries are held by landholding kin groups and Aboriginal Christians who reject traditional ritual life continue to adhere to protocols of country. Sherry Magill, a young AOG adherent, told me that gardiya (white people), but not Aboriginal people, could ignore kinbased protocols without shame and without fear of retribution. When travelling through other people's countries, Sherry's behaviour was always watchful and circumspect. She told me, 'You're all right. You're a gardiya' (McDonald 2010: 61).

And when younger Christians encounter unendurable stress in their lives such as the murder of a close relative, they look for, and find, comfort not in Christian doctrine or in church activities, but in kin relationships and family solidarity. 
In Halls Creek this includes sitting down in the main street park, participating in card games, and listening to Gija and Jaru storytelling which links the present with the past, the living with the dead, and contemporary events with the Dreaming.

\section{Conclusion}

Extreme religious views, developing on the Eurasian Steppe and cosmicised by Zoroastrianism have, in Jewish and Christian traditions, taken on the status of universal truths. Cultural amnesia renders opaque to religious believers the socially constructed nature of their concepts, texts and orders of truth. The cultural amnesiac (spirit of forgetting) which was hard at work in the Persian period, erasing particularistic antecedents of Judaism, is at work today silencing and suppressing peculiar and particularistic hunter-gatherer cosmologies.

A Foucauldian archaeological analysis reveals parallels in the development of Western Christianity and Aboriginal Christianity in East Kimberley. In both cases, particularistic traditions are denigrated and suppressed by a universalising world view. Rather than following Christian missionaries' attempts to demonise and suppress hunter-gatherer cosmologies (see Richards and Hudson 1990: 94; Hansen 1992: 53; Burke 1998: 35; Zucker 2005: 175; McCoy 2008: xiixiii; McMaster 2008: 204), students of Aboriginal Christianity can consider Ian Keen's understandings of Yolngu Christianity as an attempt by Yolngu people to develop a 'common moral order' (Keen 1994: 287). They can recognise and work with postcolonial theologians' attempts to develop a theology of religious pluralism and a pneumatology of 'many spirits' (Kim 2007).

\section{Postscript}

On my return to East Kimberley in 2014, I was surprised to find some major shifts in church affiliation and in Christian/sinner alignment. Some Christians who were fiercely loyal to the new AOG church have returned to the UAM church of their youth. Some of the most strident Holy Spirit Christians, including a prominent church leader, have returned, permanently it would seem, to a drinking lifestyle. ${ }^{23}$ Others continue the endless churchgoer/backslider cycles of

23 One woman who attended the AOG church because her brother-in-law refused to maintain her vehicle otherwise, has (on her brother-in-law's death) returned to the UAM church. Another woman who, as a result of a dream which she attributed to God, changed from heavy drinker to enthusiastic UAM member, has (after the premature death of her husband), returned to a seemingly permanent drinking lifestyle. 
half-Christianity. Extreme religious ideas (particularly apocalyptic eschatologies and unmediated dualisms) continue to be engaged with, blurred and subverted according to older, more humane (kin-based) traditions.

\section{Acknowledgements}

I thank Ngoonjuwah Aboriginal Council for permission to conduct research with East Kimberley people in the Halls Creek region. I especially thank Vera Cox, Mona Green, Doris Fletcher, Jugarie, Bill and Bessie Matthews, Ruth Mills, Barbara Sturt, Janice Hargraves, Kathy Ryder and Donald Cox for contributing their cultural knowledge to this chapter. Many thanks to Peter Toner for his careful reading of earlier drafts of this chapter and for his helpful comments and advice. Thanks to the two anonymous reviewers for their comments on an earlier draft of this chapter.

\section{References}

Alexander, P.J. 1985. The Byzantine Apocalyptic Tradition. Berkeley: University of California Press.

Allis, O.T. 2001. Prophecy and the Church. Eugene, OR: Wipf and Stock.

Asad, T. 1993. Genealogies of Religion: Discipline and Reasons of Power in Christianity and Islam. Baltimore: John Hopkins University Press.

Balmer, R. n.d. Apocalypticism in American Culture. National Humanities Center. Accessed online 20 January 2015. nationalhumanitiescenter.org/ tserve/twenty/tkeyinfo/apocal.htm.

Barnhart, R.K. 1995. The Barnhart Concise Dictionary of Etymology. New York: Harper Collins.

Beckwith, C. 2009. Empires of the Silk Road: A History of Central Eurasia from the Bronze Age to the Present. Princeton: Princeton University Press.

Bhabha, H. 1994. The Location of Culture. London: Routledge.

Berkhofer, R.F. 1995. Beyond the Great Story: History as Text and Discourse. Cambridge, MA: Harvard University Press.

Bos, R. 1988. Jesus and the Dreaming: Religion and Social Change in Arnhem Land. PhD Thesis, University of Queensland, Brisbane. 
Boyarin, D. 2004. The Christian invention of Judaism: the Theodosian Empire and the Rabbinic refusal of religion. Representations 85: 21-57.

Boyce, M. 1984a. Persian religion in the Achemenid age. In W.D. Davies and L. Finkelstein (eds), The Cambridge History of Judaism Volume 1: Introduction: The Persian Period, pp. 279-307. Cambridge: Cambridge University Press.

Boyce, M. 1984b. On the antiquity of Zoroastrian Apocalyptic. Bulletin of the School of Oriental and African Studies 47: 57-75.

Burke, D. 1998. Dreaming of the Resurrection: A Resurrection Story. Sydney: Mary MacKillop Foundation.

Chadwick, H. 1990. The Early Church. London: Penguin.

Chidester, D. 2000. Christianity: A Global History. San Francisco: HarperCollins.

Clark, P. 1998. Zoroastrianism: An Introduction to an Ancient Faith. East Sussex, UK: Sussex Academic Press.

Cohen, S. 2006. From the Maccabees to the Mishnah. Louisville: Westminster John Knox Press.

Cohn, N. 2001. Cosmos, Chaos, and the World to Come: The Ancient Roots of Apocalyptic Faith. Second edition. New Haven/London: Yale University Press.

Collins, J.J. 1998. The Apocalyptic Imagination: An Introduction to Jewish Apocalyptic Literature. Second edition. Grand Rapids, MI/Cambridge, UK: William B. Eerdmans.

Dawson, D. 1992. Allegorical Readers and Cultural Revision in Ancient Alexandria. Berkeley: University of California Press.

Dean, M. 1994. Critical and Effective Histories: Foucault's Methods and Historical Sociology. London/New York: Routledge.

Duling, D.C. 2010. The Gospel of Matthew. In D.E. Aune (ed.), The Blackwell Companion to the New Testament, pp. 296-318. Oxford: Wiley-Blackwell.

Fitzgerald, T. 2000. The Ideology of Religious Studies. New York: Oxford University Press.

Foltz, R. 1999. Religions of the Silk Road: Overland Trade and Cultural Exchange from Antiquity to the Fifteenth Century. New York: St Martin's Press.

Graff, H. 1991. The Legacies of Literacy: Continuities and Contradictions in Western Culture and Society. Bloomington, IN: Indiana University Press. 
Hannam, J. 2009. God's Philosophers: How the Medieval World Laid the Foundations of Modern Science. London: Icon Books.

Hansen, K.C. and L.E. 1992. Pintupi/Luritja Dictionary. Third edition. Alice Springs: Institute for Aboriginal Development.

Herrero de Jáuregui, M. 2007. Orphic ideas of immortality: traditional Greek images and a new eschatological thought. In M. Labahn and M. Lang (eds), Lebendige Hoffnung-Ewiger Tod?! Jenseitsvorstellungen im Hellenismus, Judentum und Christentum, pp. 247-73. Leipzig: Evangelische Verlagsanstalt.

Hume. L. 1989. Yarrabah: Christian Phoenix: Christianity and Social Change on an Australian Aboriginal Reserve. PhD Thesis, University of Queensland, Brisbane.

Keen, I. 1994. Knowledge and Secrecy in an Aboriginal Religion. Oxford: Clarendon Press.

Kellens, J. 1989. Avesta. Encyclopedia Iranica 3, pp. 35-44. New York: Routledge and Kegan Paul.

Kim, K. 2007. The Holy Spirit in the World: A Global Conversation. Maryknoll, NY: Orbis.

King, K. 2003. What Is Gnosticism? Cambridge, MA: Harvard University Press.

Kohler, K. and L. Blau n.d. Gehenna. Jewish Encyclopedia. Accessed online 20 January 2015: www.jewishencyclopedia.com/articles/6558-gehenna.

Kranenbarg, M. 2004. Painting Authenticity: Aboriginal Art and Knowledge in an Intercultural Space (Warmun, Western Australia). MA Thesis, University of Nijmegen, Netherlands.

Lee, K.J. 2011. The Authority and Authorisation of Torah in the Persian Period. Leuven: Peeters.

McCoy, B.F. 2008. Holding Men: Kanyirninpa and the Health of Aboriginal Men. Canberra: Aboriginal Studies Press.

McDonald, H. 2001. Blood, Bones and Spirit: Aboriginal Christianity in an East Kimberley Town. Melbourne: Melbourne University Press.

McDonald, H. 2010. Universalising the particular? God and Indigenous spirit beings in East Kimberley. The Australian Journal of Anthropology 21: 51-70.

McMaster, N. 2008. The Catholic Church in Jaru and Gija Country: Reworking a Context of Evangelisation in the Kimberley. Melbourne: David Lovell Publishing. 
Nigosian, S.A. 1993. The Zoroastrian Faith: Tradition and Modern Research. Montreal and Kingston: McGill-Queen's University Press.

Pagels, E. 2003. Beyond Belief: The Secret Gospel of Thomas. New York: Random House.

Papaioannou, K.G. 2004. Places of Punishment in the Synoptic Gospels. PhD Thesis, Durham University, UK.

Pratt, M.L. 1991. Arts of the contact zone. Profession 91: 33-40.

Rabinow, P. 1986. Representations are social facts: modernity and postmodernity in anthropology. In J. Clifford and G.E. Marcus (eds), Writing Culture: The Poetics and Politics of Ethnography, pp. 234-61. Berkeley: University of California Press.

Repas, M.A. 2009. From Gehinnom to Hell: An etymological and conceptual history. Rothberg International School, The Hebrew University of Jerusalem. Accessed online 20 January 2015: exploratorius.files.wordpress. com/2009/05/from-gehinnom-to-helll.pdf.

Richards, E. and J. Hudson 1990. Walmajarri-English Dictionary. Darwin, NT: Summer Institute of Linguistics.

Rowland, W. 2001. Galileo's Mistake: A New Look at the Epic Confrontation between Galileo and the Church. New York: Arcade Publishing.

Rudman, D. 2001. The use of watery imagery in descriptions of Sheol. Zeitschriftfür die Alttestamentliche Wissenschaft 113(2): 240-4.

Russell, D.S. 1994. Prophecy and the Apocalyptic Dream: Protest and Promise. Peabody, MA: Hendrickson Publishers.

Russell, J.B. 1977. The Devil: Perceptions of Evil from Antiquity to Primitive Christianity. Ithaca, NY: Cornell University Press.

Russell, J.B. 1997. A History of Heaven. Princeton: Princeton University Press.

Settegast, M. 2005. When Zarathustra Spoke: The Reformation of Neolithic Culture and Religion. Costa Mesa, CA: Mazda Publishers.

Shaked, S. 1984. Iranian influence on Judaism. In W.D. Davies and L. Finkelstein (eds), The Cambridge History of Judaism, vol. 1, pp. 308-25. Cambridge: Cambridge University Press.

Shanks, H. 1998. The Mystery and Meaning of the Dead Sea Scrolls. New York: Random House. 
Silverman, D.P. 1991. Divinity and deities in ancient Egypt. In B.E. Shafer (ed.), Religion in Ancient Egypt: Gods, Myths, and Personal Practice, pp. 7-81. Ithaca, NY: Cornell University Press.

Skjaervo, P.O. 2011. The Spirit of Zoroastrianism. New Haven and London: Yale University Press.

Slotte, I. 1997. We Are Family, We Are One: An Aboriginal Christian Movement in Arnhem Land, Australia. PhD Thesis, The Australian National University, Canberra.

Smith, J.Z. 1987. To Take Place: Toward Theory in Ritual. Chicago: University of Chicago Press.

Turner, J.M. 2002. John Wesley: The Evangelical Revival and the Rise of Methodism in England. London: Epworth Press.

United Church. 1974. Free to Decide: The United Church in North Australia Commission of Enquiry, Arnhem Land. Darwin: The United Church.

Vermes, G. 2004. The Complete Dead Sea Scrolls in English. Fifth edition. London: Penguin Books.

Volney, C.F. de. 1791. Les Ruines, ou Meditations sur les Revolutions des Empires, vol 1. Paris.

Woodburn, J. 1982. Egalitarian societies. Man 17(3): 431-51.

White, L.M. 2004. From Jesus to Christianity. New York: HarperCollins.

Wrigley, M. 1992. Jaru Dictionary. Draft edition. Halls Creek, WA: Kimberley Language Resource Centre.

Zaleski, C. 2012. Purgatory. Encyclopadia Britannica Online. Encyclopædia Britannica Inc. Accessed online 20 January 2015: www.britannica.com/ EBchecked/topic/483923/purgatory/.

Zucker, M. 2005. From Patrons to Partners: A History of the Catholic Church in the Kimberley, WA. Second edition. Fremantle: University of Notre Dame Australia Press. 
This text is taken from Strings of Connectedness: Essays in Honour of Ian Keen, edited by Peter Toner, published 2015 by ANU Press, The Australian National University, Canberra, Australia. 